\title{
Zeranol enhances leptin-induced proliferation in primary cultured human breast cancer epithelial cells
}

\author{
PINGPING XU ${ }^{1,4}$, WEIPING YE ${ }^{1}$, HONG LI ${ }^{1,2}$, SHU-HONG LIN ${ }^{1}$, \\ CHIEH-TI KUO ${ }^{1}$, ERIC FENG ${ }^{1}$ and YOUNG C. LIN ${ }^{1,3}$
}

\begin{abstract}
${ }^{1}$ Laboratory of Reproductive and Molecular Endocrinology, College of Veterinary Medicine; ${ }^{2}$ Division of Pharmaceutical Science, College of Pharmacy, The Ohio State University; ${ }^{3}$ The Ohio State University Comprehensive Cancer Center, Columbus, OH 43210, USA; ${ }^{4}$ Jinhua College of Profession and Technology, Jinhua, Zhejiang 321017, P.R. China
\end{abstract}

Received March 22, 2010; Accepted July 1, 2010

DOI: $10.3892 / \mathrm{mmr} .2010 .342$

\begin{abstract}
Breast cancer is the leading type of cancer in women in the United States. One of the known risk factors of breast cancer is obesity. Leptin is a product of the obese $(o b)$ gene and plays an important role in breast cancer development. Its expression is up-regulated in obesity and it promotes breast cancer cell growth. Exposure to environmental estrogenic disruptors has been found to be directly related to the increase in the incidence of breast cancer. Zeranol (Z) is a non-steroidal anabolic growth promoter with potent estrogenic activity that is widely used in the US beef industry. The objective of this study was to determine the mechanisms of $\mathrm{Z}$ - and leptininduced proliferation of primary cultured human breast cancer epithelial cells (HBCECs). A cell proliferation assay was used to determine the extent to which $\mathrm{Z}$ is capable of enhancing the mitogenic activity of leptin in HBCECs. RT-PCR was used to explore the possible mechanisms by quantifying the transcription of cyclin D1 and ObR genes. Our results demonstrated that when the HBCECs were pre-treated with $3 \mathrm{nM}$ leptin for $24 \mathrm{~h}$, the sensitivity to $\mathrm{Z}$ exposure greatly enhanced the mitogenic action of leptin. The experimental data observed show that there is interaction between leptin and $\mathrm{Z}$ in HBCEC growth.
\end{abstract}

\section{Introduction}

Breast cancer is the most commonly diagnosed type of cancer among women and was the second leading cause of mortality among women in 2008 (1). One of the currently known risk factors of breast cancer is obesity, which has become a major public health concern (2). The incidence of breast cancer is increased with obesity, and morbidity is also increased in obese cancer patients as compared to cancer patients with

Correspondence to: Dr Young C. Lin, Laboratory of Reproductive and Molecular Endocrinology, College of Veterinary Medicine, The Ohio State University, Columbus, OH 43210, USA

E-mail: 1in.15@osu.edu

Key words: zeranol, leptin, leptin receptor, breast cancer, primary cultured human breast cancer epithelial cells normal or low weight $(3,4)$. The relationship between breast cancer and obesity has been studied for many years (2).

Leptin, a product of the obese $(o b)$ gene, has been studied since its discovery in 1994 (5). It is a 167-amino acid protein with a molecular mass of $16 \mathrm{kDa}$. Besides its involvement in appetite regulation and energy balance (6), leptin has a number of other regulatory functions. They include ensuring normal mammary gland development, bone development, fetal development, sex maturation, angiogenesis, lactation, hematopoiesis and immune responses (7).

Leptin promotes breast cancer cell growth by signaling through its receptors and by directly affecting the estrogen receptor (ER) pathway $(3,7)$. The leptin receptor (ObR), localized in the cell membrane of various tissues including breast cancer tissue (6), has been identified as having one long isoform and five short isoforms (2). Both the short and long isoforms are expressed in normal mammary epithelial cells during pregnancy and lactation (2,3). Such expression suggests an autocrine action of leptin in the regulation of mammary gland growth and development. Furthermore, since it is commonly expressed in breast cancer, this gene could serve as a breast cancer molecular biomarker or a prognostic or diagnostic indicator (8).

Similar to other growth factors and cytokines, leptin and its receptor are present in human serum and many organs, and play a role in human cancer development (7). Since leptin was found to be associated with several types of cancer (9), researchers attempted to find the relationship and mechanisms of leptin action in prostate cancer (10), gastric cancer (11), oral cancer (12), esophageal adenocarcinoma (13), hepatocellular carcinoma (14), gallbladder cancer (15) and breast cancer (16-22). Ishikawa et al found that leptin was overexpressed in breast cancer cells (23) and concluded that high leptin levels in obese breast cancer patients may play a role in the development of antiestrogen resistance $(21,23)$. Leptin is not expressed in normal breast tissue, but exists near malignant breast lesions (8), while its receptors were detectable in breast cancer cells, but undetectable in normal mammary epithelial cells (23). In addition to its mitogenic effects, leptin promotes the proliferation of the human breast cancer cell line T47-D (9). A high level of leptin may contribute to the development of a more aggressive malignant phenotype (24). The power of leptin to stimulate human MCF-7 cell growth and its ability to 
counteract the effects of ICI 182,780 , which is a pure estrogen antagonist approved for the treatment of breast cancer patients who fail to respond to tamoxifen therapy, strongly suggests that leptin acts as a paracrine/endocrine growth factor towards mammary epithelial cells $(21,22)$.

Estrogen has been regarded as a positive regulator of leptin production (25). Serum leptin levels in breast cancer patients are significantly higher than levels in a control group (26). Thorn et al found that estrogen modulates ObR expression in some estrogen-responsive tissues $(25,27)$.Zearalenone, a stable natural product that mimics estrogen activity, is a carcinogen that is regarded as hazardous to human health (28). Zeranol $(\mathrm{Z})$, produced from Zearalenone, is a non-steroidal anabolic growth promoter with potent estrogenic activity approved by the FDA that is widely used to stimulate cattle growth in the US beef industry (29). Both Zearalenone and $\mathrm{Z}$ bind to the active site of human ER $\alpha$ and $E R \beta$ in a similar manner to $17 \beta$-estradiol (30). As a food contaminant, $\mathrm{Z}$ is very hard to avoid (28). Researchers have reported that $\mathrm{Z}$ does not affect the serum concentration of leptin in growing wethers (31). At a low concentration, $\mathrm{Z}$ increases ER $\alpha$-positive cell growth, but at higher concentrations it reduces the proliferation of both ER $\alpha$-positive and ER $\alpha$-negative cell lines (32). Moreover, our previous data showed that $\mathrm{Z}$ transforms the human normal breast epithelial cell line MCF-10A and increases primary cultured human normal and cancerous breast epithelial cell growth in a dose-dependent manner (29). It also down-regulates expression of the estrogen-regulated human breast cancer candidate suppressor gene protein tyrosine phosphatase $\gamma($ PTP $\gamma)$ (33). Furthermore, we found that implantation of $\mathrm{Z}$ in beef heifers greatly induces pre-adipocyte growth by up-regulating cyclin D1 and down-regulating P53 expression (34). We also found that $2.5 \% \mathrm{Z}$ containing sera harvested from 60-day post-Z-implanted beef cattle ( $72 \mathrm{mg} \mathrm{Z}$ pellets) was capable of transforming the human normal breast epithelial cell line MCF-10A to neoplastic breast cancer cells within a 21-day culture. The objective of this study was to investigate the interactions of leptin and $\mathrm{Z}$ in primary cultured human breast cancer epithelial cells.

\section{Materials and methods}

Reagents. Recombinant human leptin was purchased from R\&D Systems (Minneapolis, MN, USA) and was prepared as a stock solution of $1 \mathrm{mg} / \mathrm{ml}$ in sterile $20 \mathrm{mM}$ Tris/ $\mathrm{HCl}$ (pH 8.0) then stored at $-20^{\circ} \mathrm{C}$. Z was purchased from Sigma Chemical Co. (St. Louis, MO, USA) and was prepared as a $50 \%$ stock solution in dimethyl sulfoxide (DMSO).

Human breast normal and cancer tissues. Human breast normal and cancer tissues were obtained through the Tissue Procurement Program of the Ohio State University Comprehensive Cancer Center Hospital (Columbus, OH, USA). At the time of procurement, the tissue samples were placed in Dulbecco's modified Eagle's medium and Ham's F12 medium (1:1) (DMEM/F12) without phenol red (Sigma Chemical Co.) and stored at $4^{\circ} \mathrm{C}$ before transfer to the laboratory.

Primary cultured human breast normal and cancer epithelial cell isolation. Fourteen breast normal and cancer tissues (six matched tissues; both the normal and cancer tissues were from the same patients) from 11 patients were sterilized in $70 \%$ ethanol for $30 \mathrm{sec}$ and then washed three times with fresh DMEM/F12. The breast normal and cancer tissues were minced and then digested using digestion buffer, which consisted of phenol red-free high calcium DMEM/F12 (1.05 $\mathrm{mM} \mathrm{CaCl}{ }_{2}$ ) with $2 \%$ bovine serum albumin (BSA; Invitrogen, Carlsbad, CA, USA) containing $10 \mathrm{ng} / \mathrm{ml}$ Cholera toxin (Sigma Chemical Co.), 6,300 U/ml Collagenase (Invitrogen) and $100 \mathrm{U} / \mathrm{ml}$ Hyalurinidase (Calbiochem, Gibbstown, NJ, USA). After the mixture was incubated at $37^{\circ} \mathrm{C}$ overnight, the solution was transferred to a $45-\mathrm{ml}$ tube and centrifuged in $1,200 \mathrm{rpm}$ for $5 \mathrm{~min}$. The upper layer containing oil and fat tissue was discarded and the middle and lower layers were centrifuged again. The middle layer containing stromal cells was transferred to another 45-ml tube and centrifuged. The lower layer containing pellet was washed with DMEM/F12 medium with antibiotic-antimycotic $(100 \mathrm{U} / \mathrm{ml}$ penicillin $\mathrm{G}$ sodium, $100 \mu \mathrm{g} / \mathrm{ml}$ streptomycin sulfate and $0.25 \mu \mathrm{g} / \mathrm{ml}$ amphotericin B) (Gibco BRL, Bethesda, MD, USA) and centrifuged again. This wash procedure was repeated three times. The final pellet in the tube contained primary human breast cancer epithelial cells and very few stromal cells. The pellet was re-suspended in $10 \mathrm{ml}$ low calcium $(0.04 \mathrm{mM}$ $\left.\mathrm{CaCl}_{2}\right)$ DMEM/F12 medium supplemented with $10 \%$ of low calcium fetal bovine serum (FBS) (Atlanta Biologicals, Norcross, GA, USA) and then transferred into a $75-\mathrm{cm}^{2}$ flask for culturing.

Cell culture. The isolated primary cultured human breast normal epithelial cells (HBNECs) and human breast cancer epithelial cells (HBCECs) were cultured in a $75-\mathrm{cm}^{2}$ culture flask in a humidified incubator $\left(5 \% \mathrm{CO}_{2}, 95 \%\right.$ air, $\left.37^{\circ} \mathrm{C}\right)$ with $10 \mathrm{ml}$ low-calcium $(0.04 \mathrm{mM} \mathrm{CaCl}$ ) DMEM/F12 mixture (Atlanta Biologicals) supplemented with $10 \%$ of Chelex-100 (Bio-Rad Laboratories, Richmond, CA, USA) treated with FBS (Gibco Cell Culture ${ }^{\mathrm{TM}}$, Grand Island, NY, USA). The low calcium DMEM/F12 medium, which guaranteed the purity of HBNECs and HBCECs, was changed every 2 days (29). When the cells reached $85-90 \%$ confluence, they were washed with $10 \mathrm{ml}$ of calcium- and magnesium-free phosphate buffered saline (PBS; pH 7.3) and then dissociated with $3 \mathrm{ml}$ of $0.25 \%$ trypsin-5.3 mM EDTA (Gibco Cell Culture ${ }^{\mathrm{TM}}$ ) for $10 \mathrm{~min}$ at $37^{\circ} \mathrm{C}$. The trypsinization was stopped by the addition of $10 \mathrm{ml}$ DMEM/F12 medium with $10 \%$ FBS. After centrifugation for $5 \mathrm{~min}$, the cells were re-suspended in low-calcium DMEM/ F12 medium with $10 \%$ low-calcium FBS, and sub-cultured into $75-\mathrm{cm}^{2}$ culture flasks at a ratio of 1:5 flasks. All experiments were conducted on primary cultured HBNECs and HBCECs not generated beyond the fourth passage.

Cell proliferation (MTT) assay. Medium (100 $\mu \mathrm{l})$ containing 4,000 HBNECs and HBCECs was seeded in each well of 96-well plates in low-calcium DMEM/F12 medium and incubated at $37^{\circ} \mathrm{C}$ for $24 \mathrm{~h}$. The following day, the medium was replaced by $100 \mu \mathrm{l}$ low-calcium DMEM/F12 supplemented with $0.2 \% \mathrm{BSA}$, and was incubated at $37^{\circ} \mathrm{C}$ for another $24 \mathrm{~h}$. The HBCECs were treated with 1.5, 3, 6 and $12 \mathrm{nM}$ leptin and 5, 10 and $20 \mathrm{nM} \mathrm{Z}$ for $24 \mathrm{~h}$, while the control group was treated with $0.1 \%$ DMSO. The proliferation of HBNECs and 
HBCECs was measured by adding $20 \mu \mathrm{l}$ of a fresh mixture of 3-(4,5-dimethylthiazol-2-yl)-5-(3-carboxymethoxy-phenyl)2-(4-sulfophenyl)-2H-tetrazolium (MTS) and phenazine methosulfate (PMS) (20:1) solution (Promega, Madison, WI, USA) to each well. After incubation for $1-3 \mathrm{~h}$ at $37^{\circ} \mathrm{C}$, the OD values were measured using a kinetic microplate reader (Molecular Devices Cooperation, Menio Park, CA, USA) at $490 \mathrm{~nm}$. Cell growth was also measured and the average sensitive dose of leptin was calculated.

In an experiment investigating the sensitivity of leptininduced HBCECs to Z, 4,000 HBCECs were planted in each well of 96-well plates containing $100 \mu 1$ low-calcium DMEM/ F12 medium and incubated in $37^{\circ} \mathrm{C}$ for $24 \mathrm{~h}$. The following day, the medium was changed to $100 \mu 1$ low-calcium DMEM/ F12 supplemented with $0.2 \%$ BSA, and the HBCECs were incubated at $37^{\circ} \mathrm{C}$ for another $24 \mathrm{~h}$. The cells were treated in five groups: i) control group (CT), cells treated with $0.1 \%$ DMSO; ii) leptin treatment group (lp), cells only treated with $3 \mathrm{nM}$ leptin for $48 \mathrm{~h}$; iii) pre-treatment with leptin group (pre-lp), cells treated with $3 \mathrm{nM}$ leptin for $24 \mathrm{~h}$ and with 1.25 , 2.5 or $5 \mathrm{nM} \mathrm{Z}$ in the following $24 \mathrm{~h}$; iv) post-treatment with leptin group (post-lp), cells initially treated with $1.25,2.5$ or $5 \mathrm{nM} \mathrm{Z}$ for $24 \mathrm{~h}$ and then with $3 \mathrm{nM}$ leptin in the following $24 \mathrm{~h}$; and v) $\mathrm{Z}$ treatment group (Z), cells only treated with $1.25,2.5$ or $5 \mathrm{nM} \mathrm{Z}$ for $48 \mathrm{~h}$. All media were changed every $24 \mathrm{~h}$. After $48 \mathrm{~h}$ of treatment, cell growth was measured by the methods described above.

Cell treatment for RNA and PCR analyses. A total of $10^{5}$ viable $\mathrm{HBCEC} /$ well were seeded in 6-well plates in $5 \mathrm{ml}$ low-calcium DMEM/F12 supplemented with 10\% Chelex-100 (Bio-Rad Laboratories, Hercules, CA, USA)-treated FBS (Gibco Cell Culture $^{\mathrm{TM}}$ ) medium. Twenty-four hours later, the medium was replaced with low-calcium DMEM/F12 supplemented with $10 \%$ dextran coated charcoal (DCC) stripped FBS, and the cells were cultured overnight. After $24 \mathrm{~h}$, the medium was changed and treatment was administered to five groups: i) CT group, cells treated with $0.1 \%$ DMSO; ii) lp group, cells treated with $3 \mathrm{nM}$ leptin for $48 \mathrm{~h}$; iii) $\mathrm{Z}$ group, cells treated with $5 \mathrm{nM} \mathrm{Z}$ for $48 \mathrm{~h}$; iv) post-lp group, cells treated with $5 \mathrm{nM}$ zeranol for $24 \mathrm{~h}$ and with $3 \mathrm{nM}$ leptin in the following $24 \mathrm{~h}$; and v) pre-lp group, cells treated with $3 \mathrm{nM}$ leptin for $24 \mathrm{~h}$ and with $5 \mathrm{nM} \mathrm{Z}$ in the following $24 \mathrm{~h}$. All media were changed every $24 \mathrm{~h}$.

RNA isolation and cDNA synthesis. After the HBCECs had been treated for $48 \mathrm{~h}$, total RNA was isolated in $1 \mathrm{ml}$ TRIzol Reagent (Invitrogen) according to the manufacturer's instructions. RNA concentration was measured by the DU-70 spectrophotometer (Beckman Instruments Inc., Fullerton, CA, USA). RNA (1 $\mu \mathrm{g})$ from the cultured cells was reverse transcribed with 200 units of M-MLV reverse transcriptase (Invitrogen) at $37^{\circ} \mathrm{C}$ for $50 \mathrm{~min}$, then at $70^{\circ} \mathrm{C}$ for $15 \mathrm{~min}$ in the presence of $1 \mu 110 \mathrm{mM}$ dNTP (10 mM each dATP, dGTP, $\mathrm{dCTP}$ and dTTP at a neutral pH) (Invitrogen), $1 \mu \mathrm{l} 50 \mu \mathrm{M}$ Random hexamer (Amersham, Piscataway, NJ, USA), RNase Inhibitor (Invitrogen), $10 \mu 1$ XX First Strand buffer, $5 \mu 10.1 \mathrm{M}$ DTT and $1 \mu$ l RNase Inhibitor (Invitrogen) in a total volume of $50 \mu \mathrm{l}$ in a gradient mastercycle (Eppendorf ${ }^{\circledR}$, Westbury, NY, USA).
Reverse transcription-polymerase chain reaction (RT-PCR). RT-PCR conditions were optimized for every primer pair and performed with a thermocycler Gene Amp PCR (Eppendorf ${ }^{\circledR}$ ). A volume of $2 \mu \mathrm{l}$ of the newly synthesized cDNA was used as templates for RT-PCR. $\mathrm{MgCl}_{2}$ concentration, annealing temperature and cycle number for the amplification of each of the PCR products (ER $\alpha$, cyclin D1 and ObR) were optimized. Under optimal conditions, 1 unit of platinum Taq DNA polymerase (Gibco BRL) was added for a total volume of $25 \mu \mathrm{l}$.

Primers for cyclin D1 were 5'-GCT CCT GTG CTG CGA AGT GG-3' (sense) and 5'-TGG AGG CGT CGG TGT AGA TG-3' (antisense; product size $372 \mathrm{bp}$ ). PCR conditions were: denaturing at $95^{\circ} \mathrm{C}$ for $5 \mathrm{~min}$, followed by 27 cycles at $94^{\circ} \mathrm{C}$ for $45 \mathrm{sec}, 54^{\circ} \mathrm{C}$ for $45 \mathrm{sec}, 72^{\circ} \mathrm{C}$ for $60 \mathrm{sec}$, and lastly extension at $72^{\circ} \mathrm{C}$ for $10 \mathrm{~min}$. Primers for $\mathrm{ObR}$ common domain were 5'-CAT TTT ATC CCC ATT GAG AAG TA-3' (sense) and 5'-CTG AAA ATT AAG TCC TTG TGC CCA G-3' (antisense; product size $273 \mathrm{bp}$ ). PCR conditions were: $95^{\circ} \mathrm{C}$ for $5 \mathrm{~min}$, followed by 30 cycles at $95^{\circ} \mathrm{C}$ for $40 \mathrm{sec}, 60^{\circ} \mathrm{C}$ for $50 \mathrm{sec}, 72^{\circ} \mathrm{C}$ for $50 \mathrm{sec}$, and lastly extension at $72^{\circ} \mathrm{C}$ for $10 \mathrm{~min}$. Primers for ERa were 5'-TGG CCC AGC TCC TCC TCA T-3' (sense) and 5'-AGT GGC TTT GGT CCG TCT CCT C-3' (antisense; product size $107 \mathrm{bp}$ ). PCR conditions were: $95^{\circ} \mathrm{C}$ for $5 \mathrm{~min}$, followed by 31 cycles at $95^{\circ} \mathrm{C}$ for $60 \mathrm{sec}, 60^{\circ} \mathrm{C}$ for $45 \mathrm{sec}, 72^{\circ} \mathrm{C}$ for $60 \mathrm{sec}$, and lastly extension at $72^{\circ} \mathrm{C}$ for $10 \mathrm{~min}$. cDNA from MDA-MB-231 and MCF-7 cells was used as a positive and negative control to ER $\alpha$ expression. Primers for 36B4, an internal control, were 5'-AAA CTG CTG CCT CAT ATC CG-3' (sense) and 5'-TTT CAG CAA GTG GGA AGG TG-3' (antisense; product size $563 \mathrm{bp}$ ). PCR conditions were $95^{\circ} \mathrm{C}$ for $5 \mathrm{~min}$, followed by 24 cycles at $95^{\circ} \mathrm{C}$ for $60 \mathrm{sec}, 63^{\circ} \mathrm{C}$ for $60 \mathrm{sec}, 72^{\circ} \mathrm{C}$ for $60 \mathrm{sec}$, and lastly extension at $72^{\circ} \mathrm{C}$ for $10 \mathrm{~min} .36 \mathrm{~B} 4$ is internal control whose RNA is unmodified by treatment. MCF-7 and MDA-MB-231 cells were used as positive and negative controls, respectively, to the ER $\alpha$ gene.

The final RT-PCR products $(10 \mu \mathrm{l})$ mixed with $1 \mu \mathrm{l} 10 \mathrm{X}$ loading buffer were separated on $1.5 \%$ agarose gel and visualized by staining with ethidium bromide. Electronic images were captured under a FUJIFILM LAS-3000 image system (Fujifilm Medical Systems USA, Inc., Stanford, CT, USA). The densities of specific band were quantified by ImageQuant software (Molecular Dynamics, Sunnyvale, CA, USA). The results were presented as the ratio of cyclin D1 to 36B4 and ObR to 36B4.

Statistical analysis. The results of the cell proliferation assay are presented compared to the control group as the mean \pm standard deviation (SD) of four replicate culture wells. The results of mRNA expression are presented compared to the control group as the mean $\pm \mathrm{SD}$ of three replicates. Analysis was performed using Minitab 15 software (Minitab Inc., PA, USA). Statistical difference was determined using two sample t-test analysis for independent samples. P-values of $<0.05$ were considered to represent a statistically significant difference.

\section{Results}

Leptin and $Z$ significantly increase $H B N E C$ and $H B C E C$ proliferation. Leptin significantly increased the growth of all the human breast epithelial cells isolated from 14 normal or cancer breast tissues (data not shown, $\mathrm{P}<0.05$ ). As shown in 
A

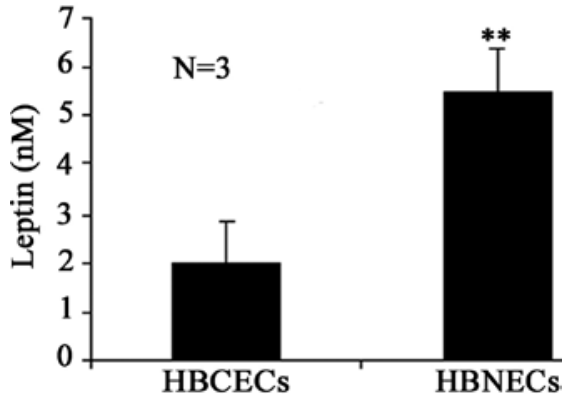

B

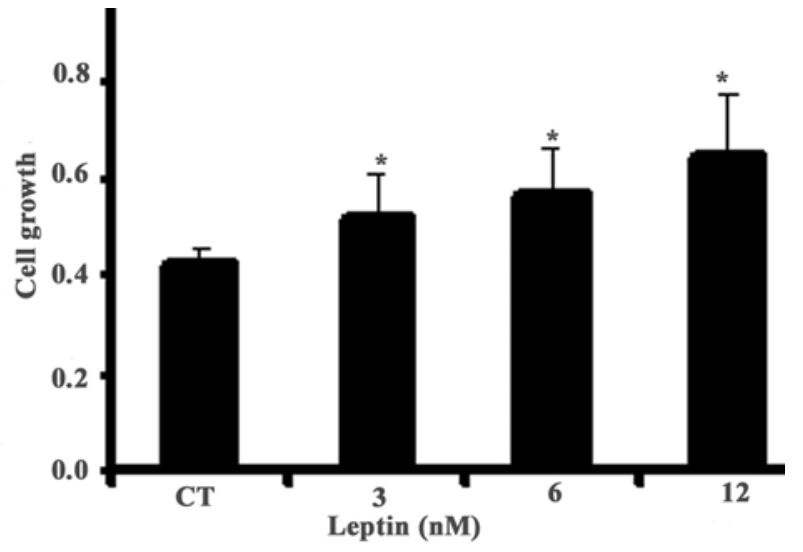

C

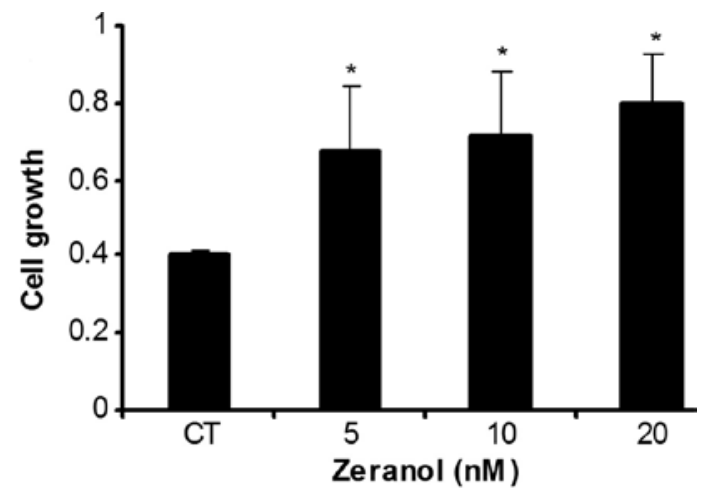

Figure 1. (A) Effective dose of leptin on primary cultured HBCEC and HBNEC growth. Primary cultured HBCECs and HBNECs were treated with $0,1.5,3,6$ and $12 \mathrm{nM}$ leptin. The average sensitive dose of leptin to HBCECs and HBNECs was calculated and compared. ${ }^{* *} \mathrm{P}<0.01$, significant difference between the HBNECs group compared to HBCEC group. (B) Effect of leptin on primary cultured HBCEC growth. Primary cultured HBCECs were treated with $0,3,6$ and $12 \mathrm{nM}$ leptin. ${ }^{*} \mathrm{P}<0.05$, significant difference in HBCEC growth compared to the control group. (C) Effect of zeranol on primary cultured HBCEC growth. Primary cultured HBCECs were treated with $0,5,10$ and $20 \mathrm{nM}$ zeranol. ${ }^{*} \mathrm{P}<0.05$, significant difference in HBCEC growth compared to the control group.

Fig. 1A, the average sensitivity concentration of leptin differs significantly between matched HBNECs and HBCECs: the average sensitivity concentration of leptin for HBNECs and HBCECs is 5.5 and $2.0 \mathrm{nM}$, respectively. Fig. $1 \mathrm{~B}$ and $\mathrm{C}$ show that both leptin and $\mathrm{Z}$ significantly increased HBCEC growth in a dose-dependent manner $(\mathrm{P}<0.05)$. Leptin at $3 \mathrm{nM}$ and $\mathrm{Z}$ at $5 \mathrm{nM}$ significantly increased the growth of HBCECs isolated from human breast cancer patients after 24-h treatment, and treatment with $5 \mathrm{nM} \mathrm{Z}$ stimulated cell growth more than that of $3 \mathrm{nM}$ leptin. The pre-lp group grew faster than the post-lp group (Fig. 2A), and the cells in the pre-lp group grew faster than those treated with leptin alone (Fig. 2B). As shown in Fig. 2A, compared to the combination of $3 \mathrm{nM}$ leptin with 1.25
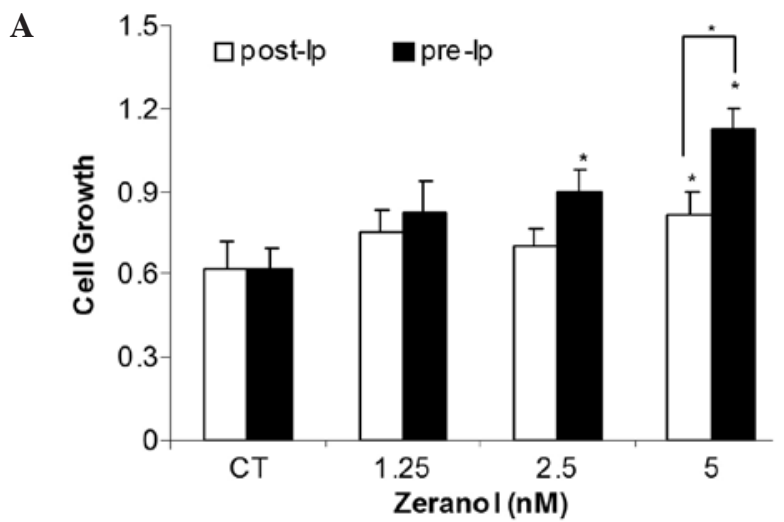

B

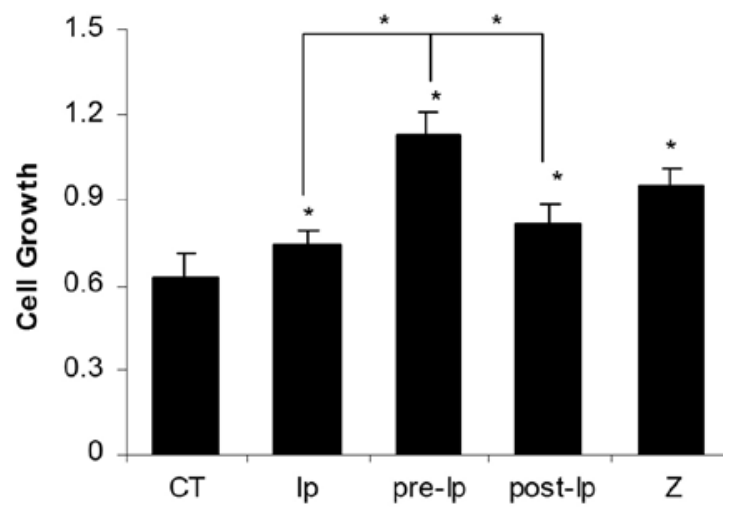

Figure 2. (A) Effects of leptin and zeranol on the proliferation of primary cultured HBCECs. HBCECs were treated with $1.25,2.5$ and $5 \mathrm{nM}$ zeranol or $3 \mathrm{nM}$ leptin in the 1st and/or $2 \mathrm{nd} 24 \mathrm{~h}$. ${ }^{*} \mathrm{P}<0.05$, significant differences in HBCEC growth compared to the control group and between the pre-lp and post-lp groups. (B) Effects of $3 \mathrm{nM}$ leptin and $5 \mathrm{nM}$ zeranol on the proliferation of primary cultured HBCECs. HBCECs were treated with $3 \mathrm{nM}$ leptin or $5 \mathrm{nM}$ zeranol in the 1st or 2nd $24 \mathrm{~h}$. HBCEC growth was most stimulated in the pre-lp group. ${ }^{*} \mathrm{P}<0.05$, significant differences in HBCEC growth compared to the control group.

and $2.5 \mathrm{nM} \mathrm{Z}$, the combination of $3 \mathrm{nM}$ leptin with $5 \mathrm{nM} \mathrm{Z}$ had the greatest effect on increasing the sensitivity of primary cultured HBCECs to $\mathrm{Z}$ for proliferation.

Pre-treatment with leptin significantly increased cyclin DI expression in ERa-positive HBCECs. HBCECs used were ER $\alpha$-positive (figure not shown). Fig. 3A shows that cyclin DI mRNA expression levels of the HBCECs were significantly increased in the lp and the pre-lp groups compared to the $\mathrm{CT}$ group $(\mathrm{P}<0.05)$.

Zeranol (5 nM) significantly increases ObR expression in HBCECs. As shown in Fig. 3B, ObR gene expression was significantly increased in the $\mathrm{Z}$ and post-lp groups compared to the control $(\mathrm{P}<0.05)$.

\section{Discussion}

Cyclin D1 is a cell cycle regulator that plays an important role in cell growth. The cyclin-dependent kinases (CDKs) cannot regulate cell growth without the cyclin subunit. By binding to cyclin D, cyclin D-CDK 4/6 constitutes the engine of the cell cycle machinery and affects the $\mathrm{G}_{1}$ phase of cell growth. The cyclin D1 level is modulated by changes in growth factors in the medium used to culture cells. Leptin stimulates breast 
A
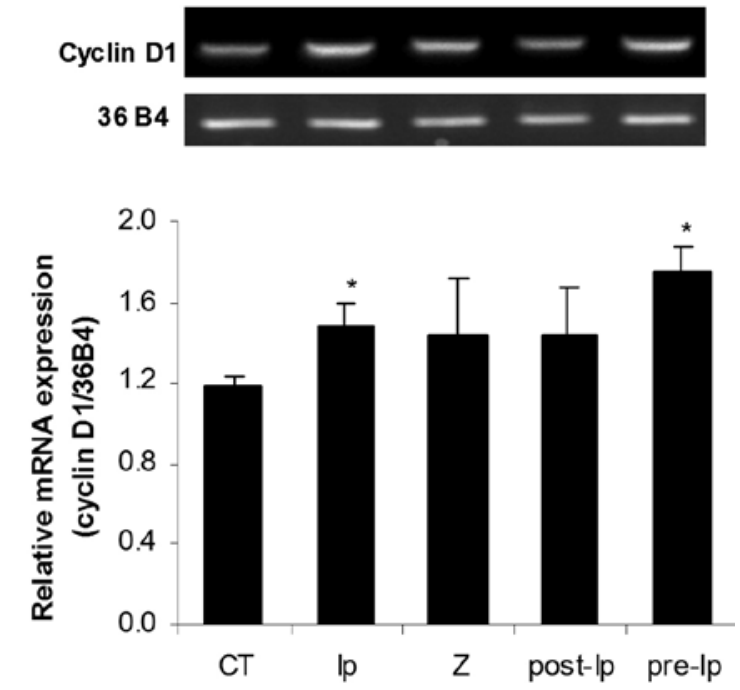

B

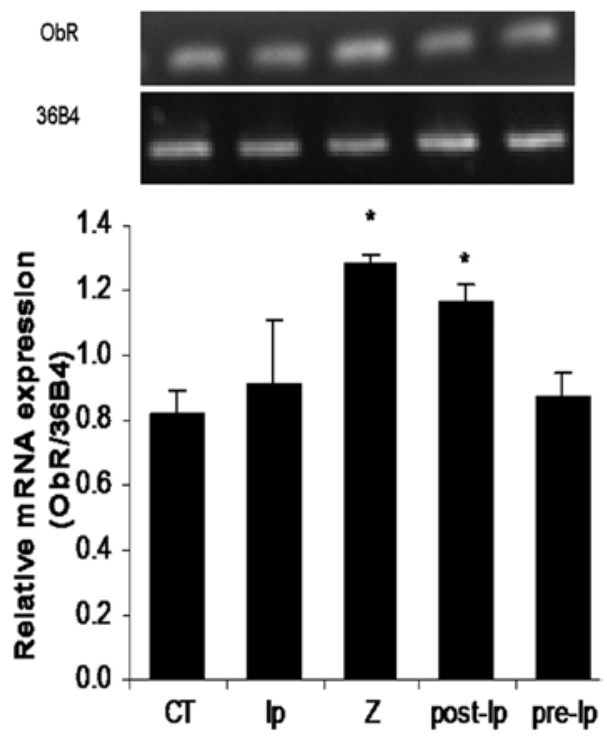

Figure 3. (A) Effects of leptin and zeranol on cyclin D1 expression in HBCECs. HBCECs were treated with $3 \mathrm{nM}$ leptin or $5 \mathrm{nM}$ zeranol in the 1st or 2 nd 24 h. ${ }^{*} \mathrm{P}<0.05$, significant differences in cyclin D1 expression compared to the control group. (B) Effects of leptin and zeranol on ObR expression in HBCECs. HBCECs were treated with $3 \mathrm{nM}$ leptin and $5 \mathrm{nM}$ zeranol in the 1 st or 2 nd $24 \mathrm{~h}$. ${ }^{*} \mathrm{P}<0.05$, significant differences in ObR gene expression compared to the control group.

cancer cell growth by up-regulating cyclin Dl expression (35). Moreover, Garofalo et al found that leptin modulates estrogen synthesis and ER $\alpha$ activity $(7,36)$. Besides controlling the cell cycle, cyclin D1 was found to be associated with ER (37). Cyclin D1 binds to the ER and stimulates its transcriptional activities. The cyclin D1/ER complex may play a role in stimulating tumor cell proliferation. Since leptin stimulates estrogen biosynthesis through the induction of aromatase activity and the modulation of ER $\alpha$ activity, it has been characterized as a growth factor for breast cancer. High levels of leptin in obese breast cancer patients may play a significant role in breast cancer cell proliferation, invasion and metastasis $(7,38)$. The molecular action of leptin was initiated by leptin binding to the leptin receptor ObR. It is necessary to understand how leptin and $\mathrm{Z}$ affect cyclin D1 and ObR mRNA expression in breast cancer epithelial cells isolated from the cancerous tissues of human breast cancer patients.
Our data indicate that $5 \mathrm{nM} \mathrm{Z}$ alone does not affect cyclin D1 expression in primary cultured human breast cancer epithelial cells, while HBCECs exposed to $3 \mathrm{nM}$ leptin for $24 \mathrm{~h}$ and then to $\mathrm{Z}$ in the following $24 \mathrm{~h}$ do significantly exhibit an increase in the expression of cyclin D1 as compared to the control group. Our results, determined using a cell proliferation assay, showed that ER $\alpha$-positive HBCEC proliferation was significantly increased by treatment with $5 \mathrm{nM} \mathrm{Z}$ for $24 \mathrm{~h}$, and that treatment with $5 \mathrm{nM} \mathrm{Z}$ stimulated cell growth more than $3 \mathrm{nM}$ leptin. However, when these cells were pre-treated with $3 \mathrm{nM}$ leptin for $24 \mathrm{~h}, 2.5 \mathrm{nM} \mathrm{Z}$ for $24 \mathrm{~h}$ significantly increased HBCEC growth, compared to their respective control groups. A significant difference in cell growth was found between the pre-lp and post-lp groups (Fig. 2A). The pre-lp group demonstrated the highest stimulation of HBCEC growth compared to any other group. This result supports our hypothesis that in the pre-lp group, the sensitivity of primary cultured HBCECs to $\mathrm{Z}$ was increased. This is partially explained by the fact that the pre-lp group exhibits higher expression of cyclin D1. Thus, the combination of exposure of leptin and $\mathrm{Z}$ is more harmful to humans than leptin and $\mathrm{Z}$ alone. Leptin expression is up-regulated in obesity, primary breast cancer and lymph node metastasis $(7,21,35)$. The serum level of leptin in cancer patients is higher than that in a healthy control group (26). The prognosis for ObR-positive breast cancer patients is worse than that for those without leptin or ObR expression (2). Since leptin increased HBCEC sensitivity to $\mathrm{Z}$, it is possible that $\mathrm{Z}$ affected obese breast cancer patients more than cancer patients of average weight. Thus, the prognosis for obese breast cancer patients is worse, since more breast cancer patients exhibit leptin expression (9). Moreover, our MTT assay demonstrated that primary cultured HBCECs are more sensitive to leptin and $\mathrm{Z}$ than MCF-7 Adr cells (39).

A previous study found higher serum levels of leptin in a breast cancer patient group than in a control group. Our results also show that the average dose of $2 \mathrm{nM}$ leptin significantly stimulates HBCEC growth. This suggests a possible relationship between obesity and breast cancer. Moreover, the potential risk for breast cancer in obese individuals may be attributed to the consumption of Z-containing beef products. Other researchers found relationships between the consumption of red meat in adult women and an increase in breast cancer risk (40). An association between higher intake of red meat in adolescence and an increase in breast cancer risk in pre-menopausal women has also been demonstrated (41). We also found that $Z$ residues were detectable in meat harvested from Z-implanted beef heifers, though at levels much lower than the FDA legal limit of $150 \mathrm{ppb}$ (data not shown).

On the other hand, researchers have found that leptin receptors are expressed in a wide range of tumor cells, and that leptin and estrogen play roles in sustaining the growth of estrogendependent breast cancer cells (38). Similar to how estrogen modulates $\mathrm{ObR}$ expression in some estrogen-responsive tissues $(25,27)$, our previous data also indicate that $30 \mathrm{nM} \mathrm{Z}$ increases $O b R$ expression in MCF-7 Adr cells, thus affecting leptin action (39). With Z treatment, the expression of $O b R$ was increased in the HBCEC cells, and the action of leptin was amplified. This result also suggests that $\mathrm{Z}$ may be more harmful to obese breast cancer patients than to normal weight breast cancer patients in terms of breast cancer development (32). 
In conclusion, Leptin and $\mathrm{Z}$ enhance HBCEC growth via increasing cyclin DI mRNA expression, and Z strengthens the effect of leptin. Our laboratory is the first to reveal that leptin increases the sensitivity of ER $\alpha$-positive HBCECs to Z. Furthermore, $\mathrm{Z}$ strengthens the potency of leptin by increasing $O b R$ expression in ER $\alpha$-positive HBCECs. Further investigation of interactions involving leptin and $\mathrm{Z}$ in human breast cancer epithelial cells, and the measurement of biologically active $\mathrm{Z}$ metabolites contained in sera and meat harvested from $\mathrm{Z}$ implanted beef heifers, is in progress at our laboratory.

\section{Acknowledgements}

This study was supported by NIH grant R01 ES 015212.

\section{References}

1. Jemal A, Siegel R, Ward E, et al: Cancer statistics, 2008. CA Cancer J Clin 58: 71-96, 2008.

2. Lorincz AM and Sukumar S: Molecular links between obesity and breast cancer. Endocr Relat Cancer 13: 279-292, 2006.

3. Calle EE, Rodriguez C, Walker-Thurmond $\mathrm{K}$ and Thun MJ: Overweight, obesity, and mortality from cancer in a prospectively studied cohort of U.S. adults. N Engl J Med 348: 1625-1638, 2003

4. Calle EE and Thun MJ: Obesity and cancer. Oncogene 23: 6365-6378, 2004.

5. Zhang Y, Proenca R, Maffei M, Barone M, Leopold L and Friedman JM: Positional cloning of the mouse obese gene and its human homologue. Nature 372: 425-432, 1994.

6. Rosen ED and Spiegelman BM: Adipocytes as regulators of energy balance and glucose homeostasis. Nature 444: 847-853, 2006.

7. Garofalo C and Surmacz E: Leptin and cancer. J Cell Physiol 207: 12-22, 2006

8. Caldefie-Chezet F, Damez M, de Latour M, et al: Leptin: a proliferative factor for breast cancer? Study on human ductal carcinoma. Biochem Biophys Res Commun 334: 737-741, 2005.

9. Laud K, Gourdou I, Pessemesse L, Peyrat JP and Djiane J: Identification of leptin receptors in human breast cancer: functional activity in the T47-D breast cancer cell line. Mol Cell Endocrinol 188: 219-226, 2002.

10. Mistry T, Digby JE, Desai KM and Randeva HS: Obesity and prostate cancer: a role for adipokines. Eur Urol 52: 46-53, 2007.

11. Shida D, Kitayama J, Mori K, Watanabe T and Nagawa $H$ Transactivation of epidermal growth factor receptor is involved in leptin-induced activation of janus-activated kinase 2 and extracellular signal-regulated kinase 1/2 in human gastric cancer cells. Cancer Res 65: 9159-9163, 2005.

12. Yapijakis C, Kechagiadakis M, Nkenke E, et al: Association of leptin -2548G/A and leptin receptor Q223R polymorphisms with increased risk for oral cancer. J Cancer Res Clin Oncol 135 603-612, 2009.

13. Kendall BJ, MacDonald GA, Hayward NK, et al: Leptin and the risk of Barrett's oesophagus. Gut 57: 448-454, 2008.

14. Saxena NK, Sharma D, Ding X, et al: Concomitant activation of the JAK/STAT, PI3K/AKT, and ERK signaling is involved in leptin-mediated promotion of invasion and migration of hepatocellular carcinoma cells. Cancer Res 67: 2497-2507, 2007.

15. Larsson SC and Wolk A: Obesity and the risk of gallbladder cancer: a meta-analysis. Br J Cancer 96: 1457-1461, 2007.

16. Saxena NK, Vertino PM, Anania FA and Sharma D: Leptininduced growth stimulation of breast cancer cells involves recruitment of histone acetyltransferases and mediator complex to CYCLIN D1 promoter via activation of Stat3. J Biol Chem 282: 13316-13325, 2007.

17. Frankenberry KA, Skinner H, Somasundar P, McFadden DW and Vona-Davis LC: Leptin receptor expression and cell signaling in breast cancer. Int J Oncol 28: 985-993, 2006.

18. Catalano S, Marsico S, Giordano C, et al: Leptin enhances, via AP-1, expression of aromatase in the MCF-7 cell line. J Biol Chem 278: 28668-28676, 2003.

19. Bartella V, Cascio S, Fiorio E, Auriemma A, Russo A and Surmacz E: Insulin-dependent leptin expression in breast cancer cells. Cancer Res 68: 4919-4927, 2008.
20. Yin N, Wang D, Zhang H, et al: Molecular mechanisms involved in the growth stimulation of breast cancer cells by leptin. Cancer Res 64: 5870-5875, 2004.

21. Garofalo C, Sisci D and Surmacz E: Leptin interferes with the effects of the antiestrogen ICI 182,780 in MCF-7 breast cancer cells. Clin Cancer Res 10: 6466-6475, 2004.

22. Dieudonne MN, Machinal-Quelin F, Serazin-Leroy V, Leneveu MC, Pecquery R and Giudicelli Y: Leptin mediates a proliferative response in human MCF7 breast cancer cells. Biochem Biophys Res Commun 293: 622-628, 2002.

23. Ishikawa $\mathbf{M}$, Kitayama $\mathbf{J}$ and Nagawa $\mathrm{H}$ : Enhanced expression of leptin and leptin receptor (OB-R) in human breast cancer. Clin Cancer Res 10: 4325-4331, 2004

24. Goodwin PJ, Ennis M, Fantus IG, et al: Is leptin a mediator of adverse prognostic effects of obesity in breast cancer? J Clin Oncol 23: 6037-6042, 2005,

25. Thorn SR, Meyer MJ, van Amburgh ME and Boisclair YR: Effect of estrogen on leptin and expression of leptin receptor transcripts in prepubertal dairy heifers. J Dairy Sci 90: 3742-3750, 2007.

26. Ozet A, Arpaci F, Yilmaz MI, et al: Effects of tamoxifen on the serum leptin level in patients with breast cancer. Jpn J Clin Oncol 31: 424-427, 2001.

27. Chen HP, Fan J and Cui S: Detection and estrogen regulation of leptin receptor expression in rat dorsal root ganglion. Histochem Cell Biol 126: 363-369, 2006.

28. Coe JE, Ishak KG, Ward JM and Ross MJ: Tamoxifen prevents induction of hepatic neoplasia by zeranol, an estrogenic food contaminant. Proc Natl Acad Sci USA 89: 1085-1089, 2006.

29. Liu S and Lin YC: Transformation of MCF-10A human breast epithelial cells by zeranol and estradiol-17beta. Breast J 10: 514-521, 2004.

30. Takemura H, Shim JY, Sayama K, Tsubura A, Zhu BT and Shimoi K: Characterization of the estrogenic activities of zearalenone and zeranol in vivo and in vitro. J Steroid Biochem Mol Biol 103: 170-177, 2007.

31. Narro LA, Thomas MG, Silver GA, Rozeboom KJ and Keisler DH: Body composition, leptin, and the leptin receptor and their relationship to the growth hormone $(\mathrm{GH})$ axis in growing wethers treated with zeranol. Domest Anim Endocrinol 24: $243-255,2003$.

32. Yuri T, Tsukamoto R, Miki K, Uehara N, Matsuoka Y and Tsubura A: Biphasic effects of zeranol on the growth of estrogen receptor-positive human breast carcinoma cells. Oncol Rep 16: 1307-1312, 2006

33. Liu S, Sugimoto Y, Sorio C, Tecchio C and Lin YC: Function analysis of estrogenically regulated protein tyrosine phosphatase gamma (PTPgamma) in human breast cancer cell line MCF-7. Oncogene 23: 1256-1262, 2004.

34. Ye W, Xu P, Threlfall W, et al: Zeranol enhances the proliferation of pre-adipocytes in beef heifers. Anticancer Res 29: 5045-5052, 2009.

35. Chen C, Chang YC, Liu CL, Chang KJ and Guo IC: Leptininduced growth of human ZR-75-1 breast cancer cells is associated with up-regulation of cyclin D1 and c-Myc and downregulation of tumor suppressor p53 and p21WAF1/CIP1. Breast Cancer Res Treat 98: 121-132, 2006.

36. Garofalo C, Koda M, Cascio S, et al: Increased expression of leptin and the leptin receptor as a marker of breast cancer progression: possible role of obesity-related stimuli. Clin Cancer Res 12: 1447-1453, 2006.

37. Roy PG and Thompson AM: Cyclin D1 and breast cancer. Breast 15: 718-727, 2006.

38. Hu X, Juneja SC, Maihle NJ and Cleary MP: Leptin - a growth factor in normal and malignant breast cells and for normal mammary gland development. J Natl Cancer Inst 94: 1704-1711, 2002.

39. Xu P, Ye W, Jen R, Lin S, Kuo C and Lin Y: Mitogenic activity of zeranol in human breast cancer cells is enhanced by leptin and suppressed by gossypol. Anticancer Res 29: 4621-4628, 2009.

40. Cho E, Chen WY, Hunter DJ, et al: Red meat intake and risk of breast cancer among premenopausal women. Arch Intern Med 166: 2253-2259, 2006.

41. Linos E, Willett W, Cho E, Colditz G and Frazier L: Red meat consumption during adolescence among premenopausal women and risk of breast cancer. Cancer Epidemiol Biomarkers Prev 17: 2146-2151, 2008 